い部分からの回折模様がえられるなど、種々の応用についてのべました。ついでオックスフォードの Humphley 等は, 高電圧では Bragg 条件を満足している時よりも，網平面に平行に電子線を入射させ た場合, または二次反射に Bragg 条件を合わせた方が電子の透過がよくなることを理論的, 実験的に 示しました。このシンポジュームでの Cosslett の話でもそらでしたが, ニントラストの減少より強度 の減少が厚い陚料の観察に重要であると考えているようでした。 $1 \mathrm{MeV}$ の顕微鏡は英国の A.E. I., フ ランスの GESPA 等から発表され賑やかになってきました。これにより一まわり大きい $3 \mathrm{MeV}$ の電子

顕微鏡がトゥールーズ, 日立阪大グループにより試作されました。 ディプイ教授が病気で開会式の及で 帰ったのは残念でしたが，日立阪大グループの生きた状態での生物観察の試みは注目されました。

Spraque and Wilkens は吸収を入れた動力学的理論について講演しました。普通、複素ポテンシャ ルを用いた場合, 虚数部を加えたための波動関数の変化は無視していますが, 実ポテンシャルによる分 散面が交差する附近では, この变化が大きくなるといらことです。渡辺, 上田, 福原等によって見出さ れた二次消隇効果が起る附近で重要になります。これは福原, 藤本氏（1968）によっても議論されてい ますがささらに詳細な研究が必要でしょう。

\title{
蛋白質結晶構造解析の楽しさ苦しさ
}

\section{芦田玉 一*}

蛋白研ならば蛋白質の結晶なんかその辺にゴロゴロしているのではないだろらか？ 結晶ではなくて も，すくなくともよく精製された結晶性蛋白質ならばすぐにも望むだけ手に入るだろら。これが多くの 人の偽らざる考えではないだろらか. 蛋白研に勤めるよらになった時の私もこれに近い甘い考えをもっ て来たものである。その上, 現在の日本ではかなり恵まれた研究環境にある。すなわち予算は他の機関 にくらべてかなり多いし, 設備も整っているし一一自働回折計を二組も持っていて, 今年度中にはまた また新しいのが一組入るそらだし, 計算機もあるし, 人もたくさん居るし, 一体, 何をモタモタしてい るのであろらか？ 蛋白質の解析の必要条件はほとんぞ整っているのだから．

標題を与えられて, 編集委員が何を要求されたのか明らかではなく，また，分からないままに引受け

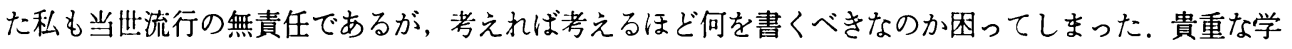
会誌を污すことにはなるが, 冒頭に述べたように，必要条件が整っていながら，我々の蛋白質の解析が 遅々として捗らないことの弁解をさせていただきたいと考えた次第である.

3 年前に生物物理といら雑誌で「生体高分子のX線解析をめぐって」といら座談会が開かれた。そこ で角戸教授が蛋白質の解析には induction period が必要であることを説明しておられる。研究室を新し く作り，いきなり蛋白質を解析する訳にはいかないのである。私が蛋白研に採用された時，6年前にな るが，研究室は角戸教授と現東工大の笹田教授らの御努力で漸く整備された時で，低分子の構造解析の ための induction period がちょらど終った時であった。 そこで，その後 2 3 年はたとえば化学会の年 会で結晶構造の部の発表件数の 1/3 1/4 を我々の研究室だけで占めるといらことになった。1966 年の 年会では今は亡き富家先生が，蛋白質の研究に関する報告はしないで低分子の解析ばかり報告するもの だから，苦々しく思われたのか，はやく蛋白質に力を注ぐよらにといら注文をつけられたことを今でも 憶えている。

表には出なかったけれども，この頃が蛋白質の抽出と結晶化を本格的に始めた時であった．蛋白研に は結晶はもちろんないし，解析するのに必要なだけの量のある蛋白質もまったくなかったのである.どん な蛋白質を解析するにしても，我々自身が抽出から始めなければならなかったのである，我々にとって， なんといってもこれが一番つらい苦しいことであった。

\footnotetext{
* 大阪大学蛋白質研究所
}

13.1-44 
選んだ蛋白質はチトクロームcであった。その前から笹田さんが牛，ハト，カッオ，マグロなどのい ろんなソースから得られるチトクローム c の検討を始めておられたが, CIT の Dickerson らが馬の酸 化型を始めているといら情報も入り, さらに材料の入手しやすさといらことも考劣てカッオの還元型于 トクローム $\mathrm{c}$ を解析しよらといらことになった。このチトクローム $\mathrm{c}$ といらのは, へム基をもった蛋白 質であるが，へモグロビンが血液中で酸素分子の担体として働くのに対して, 細胞中の呼吸系を構成す る一員で, へム鉄の

$$
\mathrm{Fe}^{++} \rightleftarrows \mathrm{Fe}^{+++}+\mathrm{e}^{-}
$$

といら可逆変化にともなって一つの電子を運ぶ役割をもつ赤い色素蛋白質である．そのペプチド鎖は脊 椎動物では一般に 104 個のアミ/酸からできている. 分子量は約 14,000 である. 当時は解析が成功し ていたのは，まだへモグロビンとミオグロビンの二つのへム蛋白質だけであったこと，チトクロームc は分子量が小さいこと, 奥貫先生といらチトクローム研究の第一人者が阪大には居られたことなどの理 由から，この蛋白質を選んだのは至極当然のなりゆきであったろう。

天然物の解析には結晶が数粒——数 $\mathrm{mg}$ 一ああれば十分である。 ところが蛋白質ではそれでは全然話 にならないのである. 1967 年に D. C. Phillips が来日したときに，どの位の量が必要であるかを聞いて みたが，ミオグロビンの解析では約 $1 \mathrm{~kg}$ の， モモグロビンだとかリゾームなどでも 600 800g のサ ンプルが使われたといらことであった。 とにかく低分解能の解析でも最低 $100 \mathrm{~g}$ は必要であることが分 かった。この $100 \mathrm{~g}$ といら量は生易しい手段では得られない量であった。 とくにチトクロームcは抽出 が非常に難しい蛋白質なのである。

静岡県にある缶詰会社の好意でカッオの心臟を大量に無償でいただけることになった．わざわざ産地 と大きさで分類したものを今までに石油缶で 70 缶ばかりもいただいたであろらか. 抽出の作業は冷凍 してあるのを解凍し, 一タを取り除き, ミンチするとい5肉体労働から始まる. その後種々の生化学的 手法を組み合わせて精製するのだが，その一行程が $5 \sim 6$ 日かかる.この抽出といら段階は学術的知見 はほとんど得られないまったくの単純労働であり, 実際にもっとも辛い段階であった。通常は 1 日に 1

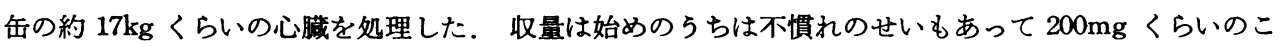
とが多かったが, 終りの頃には抽出法も確立して, $2 \mathrm{~g}$ くらい得られるよらになった. 1 週間毎日働いて 10 15g 得られた訳である. 総計して現在までに約 1トンの心臓を潰して $100 \mathrm{~g}$ あまりのチトクローム c を得ることができた。これだけを高野氏を中心にして大学院生と技官の人々とでやり遂げたのである. そのらち 1 人として生化学専門の人は居らず, 全部結晶解析を専門とする人々であった.

結晶化の条件を探すのむ大变であった。蛋白質の濃度, $\mathrm{pH}$, 温度, 塩析のための塩の種類と濃度な どのいろんな因子があり, まったくの未開の分野である。これは勘にたより, いろんな条件の試験管を 何十本もならべて結晶がでてくることを待つより術がないのである．また，その溶液の調製では $\mathrm{pH} の$ 合わせ方や塩の加え方などの手順とか, 微妙な実験法の羑が結果に大きな影響を与えるので, できるだ けいい方法を探さなければいけない. 非常な忍耐ある努力の結果, この問題もなんとか解決されて今で は数 $\mathrm{mm}$ もあるかなり大きな結晶もまちがいなく得られるようになった。

これでやっと結晶が得られたから，すぐにも強度を測定して解析へと進みたいのだが，なかなかどら してそらは問屋が卸してくれない，まだまだ訳の分からない化学実験が必要であり, 結晶学は始まらな いのである.いかに精度のよい回折強度を数多く測定し得ても，まだまだ解析にかかることはできない。 次には同型性をこわさないで重原子を結晶中に入れてやらねばならないのである，それも少なくとも二 つは必要である. 蛋白質によっては, 例えばシステイン残基があれば多くの水銀化合物と化学量論的に 結合したりして, 此較的容易に重原子置換体が得られる場合があり, また, 酵素の場合ならば, 重原子 をつけた基質を与えておくといらような方法が成立することも多いが，チトクロームcではこれもまた 非常に不利であった．Dickerson の酸化型でも事情はまったく同じで，解析がなかなか進まなかったの. もこの故であった，普段は全然お目にかかったこともない重金属化合物を何十となく買いこんで次々と テストしていった。重原子化合物を溶かしこんだ液に結晶を浸漬しては時々取り出してプリセッション 
写真を撮り強度変化を調べる訳である，約 50 個の化合物をテストしたので，その忙しさはまた大変な ものである. 何日, 何週間たっても全然入らないものがほとんど全部であったが, 化合物の種類によっ ては入りすぎて，制御しないかぎりすぐに結晶をこわしてしまうものもあった，最終的には使えそうな のが 3 個得られたが，後には全く満足できるのは一つだけであることが分かった。一つは同型性が覀く， $4.5 \AA$ かせいぜい $4 \AA$ 分解能くらいの解析にしか使えそらになく，その上悪いことには，この重原子は 特殊点に入ったのである，あと一つは結晶構造そのものを変化きせているょらで，位相決定には使えな いことが分かった。ずっと後で， $4 \AA$ 分解能の解析ができた時点で調べてみると，分子そのものがその 重原子化合物で変化しているようであった．

この頃, もら一つさらに厄介な問題がもち上がってきた。この還元型の結晶は, そのままで空気中の 酸素で自働的に酸化されることが明らかになったのである。結晶はもちろん, 母液中に保存しておくの

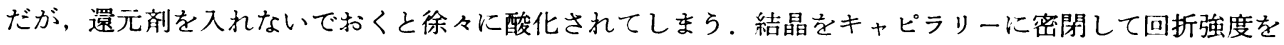
測定しているときでも同じであった。窒素気流中でキャピラリーに結晶をつめるとか，十分の還元剤を いれた母液をキャピラリーにいれておくなど，いろいろ工夫しても測定中に約 $20 \%$ の還元率の低下は 防ぐことができなかった，結晶のままで自働酸化されるのは一つの新しい結果ではあったが，解析を最 終目標とする我々には厄介な問題でしかなかった。 それで自働酸化の影響を少しでも減らすために，1 日に 700 800 個もの回折強度を測定するといらよらな実験を行ない，また，その前後ではスペクトル をとって還元率を測定することも必要となった。

トラブルはこれだけにとどまらなかった。初めのころは結晶の空間群は $P 22_{1} 2_{1}$ であった。ところが そのバッチの結晶がなくなり, 新しいソースの新しい結晶の写真をとってみると, プリセッション写真 で $\mathrm{a}$ 軸方向の層線の中間に非常に弱いけれども新しい反射がでているのを発見したのである．長時間露 出した写真でも，それまでは決してみられないことであった。いろいろ検討してみたが， a 軸が倍にな ったことは明らかであり, 非対称単位中の分子数が 2 となり, 空間群は $P 2_{1} 2_{1} 2_{1}$ となった。 その後, 現 在までいろんなりースの，またいろんなバッチの結晶を調べても $P 22_{1} 2_{1}$ の結晶はできなくなった、a 軸がただ単に倍になっただけならば，必要な回折強度の数が倍になり，計算時間が倍になるだけである が, 新しい $h$ 奇数の反射は低角では非常に弱く, 特に $d=6 \AA$ くらいまではほとんぞ認められないくら いである，すなわち，偽対称といら厄介至極な問題がさらに加わったのである.

まとめてみると, (i ) 偽対称, (ii) 特殊点にある重原子, (iii) 結晶の自働酸化, (iv) 最低限 の重原子同型置換結晶の数などである.この i と ii の二つが揃えば低分子の解析でも括手挙げになりか 权ないような問題であることは周知のことである。これだけトラブルが揃った蛋白質といらのはまだそ の例を知らない，ただ他の蛋白質にくらべてこのチトクローム c の結晶が放射線に対してかなり強く, 永持ちすることはせめてもの救いであった。

やっと強度測定に入れることになったが，やはりいろんな問題が次々とでてきた。一軸が $85 \AA ̊$ もあ ると $2 \theta$ スキャン法はできないのだが，これとて実際に実験してはじめて気付く問題である。いろいろ な経験も得たが, 我々が現在も採用している方針は「一つ一つの值の精度は多少犠牲にしても速く一組 のデータを集める」である. また, 結晶を何個かとりかえて測定を行ない, 平均するといら方法は低分 子の解析ではよいが, 蛋白質の場合には必らずしもよくはなさそらである. 結晶ごとに重原子の占有率 が変わるのが普通であり, みかけの温度因子が变わったり, 補正しきれない吸収の影響があったりする から非常に難しい問題である. 我々も何回も測定を繰り返したが，契際に解析に使らのはそのらちの一 組だけで, 他はチェックにだけ使らことにした。

強度測定には，その他にもまだまだ問題はあった。また一方，計算機用のプログラムでも，20個あま りも蛋白質の解析以外には全く無用のものばかりを作ったのだが，この測定やプログラミングの苦労と いらものは抽出と結晶化のそれに比べると楽なものであった。

一昨年春の化学会年会では, 我々の研究室はただ一つ, それも低分子ではなくて $6 \AA$ 分解能の構造を 報告することができた， $h$ 奇数の反射を無視して得た近似構造で，それは乱視の入った度のきつい近眼

13. $1-46$ 
で見たようなものではあったが，構造の主な特徴がはっきり現われて，充分满足できるものであった。 ここでやっと仕事に一段落がついたのである。しかし，实際の解析はここが出発点であった。その後 1 年間いろいろと闇雲にもがいた結果, 特殊点にある重原子と偽対称の問題がかならずしもすっきり解決 した訳ではないかもしれないが，昨年の春には $4 \AA$ の構造が得られたのである。

さらに解析を進めるためには, どうしても市と一つよい重原子同型置換体が必要であるが可能性は少 ない、しかしこの話はもうこの辺でやめよう。ここまで長々と蛋白質解析のそれも特殊な苦しさ, 辛さ, 難しさばかりを書いてきたが，これらは一般の研究報告にはほとんど出ないものである。何らかの参考 になることがあ机ばと思っている。一方，蛋白質解析に特別な楽しさがあるかどうか私には分からな い. 昨夏スイスの観光地で開かれた国際生化学会に角戸教授の御好意で出席させていただいた。これは 最大の楽しさであった。ただ私一人しか味わえなかったのは残念である。つい先日，タカアミラーゼの 結晶ができた。これも何十本といら試験管のらちの1本であったが，この日は一日気がウキウキして嬉 しかった。

最後に，一応の成果をみるまで転出していった多くの大学院生や退官されていった技官の方々の協 力がなくては全く不可能な研究であったことを特筆しておきたい、これらの多くの人々, 拉よびこの研 究の始動力となり，また最後まで御指導いただいた東工大笹田教授にこの機会をかりて厚く感謝の意を 表したい.

\section{IMA-IAGOD 日本総会}

\section{針 谷䒴*}

2 年ごとに，世界のいずれかの国において総会をおこなっている国際鈗物学連合 (International Mineralogical Association) と国際鈗床学連合 (International Association on the Genesis of Ore Deposits)の合同の総会と討論会が，8月28日より9月2日まで東京と京都で開催された。1970年の総会が， 日本でひらかれることについては，4年前のケンブリッジで IMAの総会のおりに決定され，それから 4 年間, 国内の鋐物学研究連絡委員会を中心として, 日本総会のための委員会が設立され, その準備に あたってきた。長期の準備期間があったとはいえ，この会期中はちょうど万国博覽会の会期末でもあり， 委員会を中心とした世話役は大変な労力を提供しなければならなかっただろうと想像される，とくに今 回の日本総会はIMA とIAGODの合同の総会でもあったので, その参加者数は今までにない多数で, 登録された外国人は, 同伴者もふくめて 394 名, 日本から 286 名, 計 680 名にもなった。もちろん 4 年

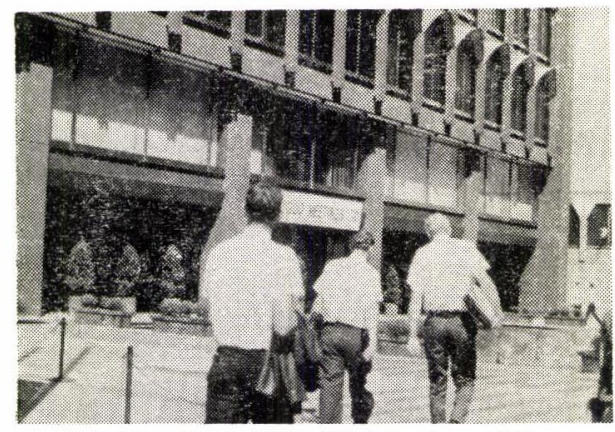

写真 1 IMA-IAGOD Meetings '70 の 東京会場

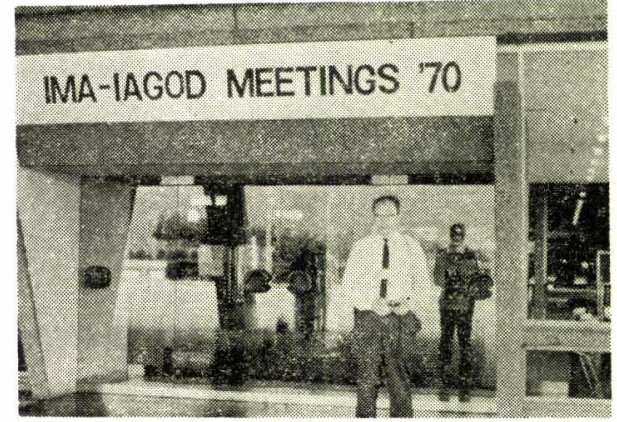

写真 2 IMA-IAGOD Meetings '70の京都会場 （会場前に立っているのはンビェトの Dr. A. A. Godovikov)

* 北海道大学理学部地質学鉱物学教室 